\title{
Research on the Plan of Action of University Civilized Campus
}

\author{
Liyun Wang ${ }^{1,2, a}$ and Lijuan Qin ${ }^{1,2, b}$ \\ ${ }^{1}$ School of Information Engineering,Zhengzhou University of Industrial Technology, \\ Zhengzhou Henan 451150,PR China \\ ${ }^{2}$ Machine learning and Data researching Institute,Zhengzhou University of Industrial Technology, \\ Zhengzhou Henan 451150,PR China \\ a912725921@qq.com \\ b654259624@qq.com
}

Keywords: Civilized campus; Civilized behavior; Two-way interaction; Mechanism

\begin{abstract}
The construction of a civilized campus is an important goal of the connotative development of colleges and universities and the goal of talent training in colleges and universities. From the aspect of moral education, the construction of a civilized campus serves to cultivate qualified college students with modern civilized behaviors, and the construction of a university's civilized campus requires every college student to achieve its own civilized behavior by regulating itself. The construction of a university's civilized campus and the cultivation of college students' civilized behavior is a two-way interactive process. Based on this relationship, long-term scientific construction and the formation of a benign interactive mechanism can achieve the "Win-win" of both.

With the continuous development of the reform of China's education system, the development of higher education has achieved certain achievements. However, in recent years, in order to conduct in-depth education on socialist core values and practically do a good job in the construction of the school's spiritual civilization, the Ministry of Education and the Central Civilization Office have provided valuable implementation opinions on the in-depth development of civilized campus activities. Therefore, it is imperative to study the content and mechanism of the establishment of a university's civilized campus. It is very important to provide some concrete and effective measures for the creation of a civilized campus.

Higher education shifts from "elite" education to popular education. In the development of colleges and universities, more and more attention is paid to the connotative development, that is, to improve the effectiveness of education and education as its goal, through the rational allocation of internal resources of the school, integrating internal factors to promote the coordination and sustainable development of the school, and enhance its own The core competitiveness, through the scientific development orientation, forms the coordinated development of its own scale of education, the construction of disciplines, the quality of education and teaching, and the benefits of running a school. Compared with the development of extension, it can create good hardware facilities and layout of campus environment for the development of schools. Connotative development reflects the soft power of college education. Colleges and universities must have their own guiding ideology for running schools, education and personnel training goals, and reasonable education. Level and school characteristics. This kind of connotative development requires the construction of an excellent campus culture and atmosphere. As a result, it is required to provide excellent talents for the society.
\end{abstract}

\section{Survey of Current Situation of Civilized Campuses in Colleges and Universities}

At present, there are still some colleges and universities lacking awareness of the construction of ecological civilization, failing to integrate ecological civilization with higher vocational education according to the requirements of the scientific development concept, and only building ecological civilization at the level of classroom theory, and lacking in the daily life of students. The hard power 
of colleges and universities can usually fully reflect its concept of running a school and show its unique charm. This is understandable. However, in recent years, some colleges and universities have overemphasized the construction of their material culture, extravagance and waste, and major construction projects. It is inconsistent with the concept of modern ecological civilization construction and is even more contrary to the concept of scientific development. Today's college students are keen to use the mobile Internet. This area is the right place for us to strengthen the promotion of ecological civilization. Green ecological pictures and ecological education videos can be posted on the mobile internet for students to learn. The construction of ecological campus requires the construction of a natural and ecological ecological campus. It requires not only perfect infrastructure, but also a beautiful and green environment. The construction of ecological campus will organically integrate ecological civilization and scientific development concept, and in the cultivation of students' awareness of ecological civilization and aesthetic awareness, it can also play a positive effect on students' emotions. The Internet+ teaching model has been devoted to the development of online teaching, online assignments, and online review to achieve resource sharing, save paper, reduce energy consumption, and protect the environment. The humanities and ecology pay attention to cultivating people's all-round development, not only to cultivate students' professional knowledge and literacy, but also to cultivate students' sense of social responsibility, humanistic quality, awareness of ecological civilization, and awareness of innovation. It is necessary to cultivate humanistic qualities on the Internet and to make everyone more equal in speech, breaking many obstacles and barriers in interpersonal relationships and balancing the humanities and ecology.

\section{Strengthen the Path of Building a Civilized Campus in Colleges and Universities}

Conscientiously practicing the socialist core values is the core content of the construction of a university's civilized campus. Colleges and universities should educate and guide teachers and students to actively cultivate and practice the core values of socialism, firmly grasp prosperity, democracy, civilization, and harmony as national-level value goals, and profoundly understand freedom, equality, justice, and the rule of law as values at the social level. Conscientiously abide by patriotism, dedication, integrity, and friendliness as civic-level values. Focusing on the basic contents of the "three advocacy", we will work hard on integration and integration. We will make full use of radio broadcasts in schools, networks, bulletin boards, and other public opinions. We will carry out publicity and education activities such as seminars, seminars, interviews, and knowledge contests to develop the core of socialism extensively. Centering on the core values of socialism to carry out "three advances" work, enhance the pertinence and effectiveness of ideological and political education in universities, organize and organize seminars on the theory of socialist core values, and unify the thoughts and actions of teachers and students to the core values of socialism. Colleges and universities should conduct in-depth education in the promotion of socialism and Chinese dreams with Chinese characteristics. For example, colleges and universities in Henan can focus on the "three countries' strategic planning," "four Henan," "two constructions," and "one carrier and three systems," and carry out in-depth development of socialism with Chinese characteristics, Chinese dreams, and publicity and education for reform and opening up. Guide the teachers and students to strengthen the awareness of reform and opening up, work hard to make progress, and sense of responsibility and responsibility. Colleges and universities should carry out in depth the theme education activities of "My China Dream" and carry out in-depth thematic education activities that love learning, love labor, and love the motherland; they must actively implement the "four clear" tasks and clearly explain the basics of Chinese dreams to teachers and students. The connotation is the prosperity of the country, the rejuvenation of the nation, and the well-being of the people. It must be clear that realizing China's dream in China must adhere to the Chinese road under the party's leadership, carry forward the spirit of China, and condense China's strength. It must be clear that the Chinese dream must rely on the people's joint efforts to achieve this. To achieve lofty ideals must be hard work, guide teachers and students to see their own interests from the Chinese dream, and use Chinese dreams to better condense teachers and students 
in colleges and universities into a "community of interest" and a "fate community".

Morality is the ideological foundation of civilization, the basic code of conduct for social civilization, and the discipline of self-discipline. A noble personality must first have a noble morality." Strengthening the moral construction in colleges and universities is the common responsibility of the teachers and students and the specific practice of governing the country with morality. In-depth implementation of civic moral construction projects, organize and carry out various forms of ethical practice activities, enhance the moral quality of teachers and students. One is the promotion of education. Grasping important links that influence the formation and development of moral concepts, intensively develop patriotism, collectivism, and socialist education so that teachers and students in colleges and universities understand the basic requirements of socialist ethics, distinguish between right and wrong, promote truth, goodness, beauty, and counterfeiting, evil, and ugliness. The second is public opinion guidance. Colleges and universities should use a variety of forms to carry out a wide range of moral model learning and propaganda activities, and vigorously promote the advanced deeds of "moral model" and "good neighbors". A wide range of "moral models into the campus" tour activities and "moral model story exchange" campus tour activities to promote the advanced model of morality into the campus. It is necessary to widely carry out the "I recommend, I comment on good people around" and "Good People in Henan" selection activities, build and make good use of moral lectures, form a moral education platform for teachers and students, spread advanced culture, promote social uprightness, and guide teachers and students Si Qi. The third is to carry out ethical practice activities to guide young students to disseminate red genes. Vigorously advocate civilized tourism, civilized transportation, and civilized dining tables, and cultivate the consciousness of observing the virtues of compliance. Strengthen the grain-saving, water-saving, energy-saving education, and carry out energy-saving campus creation activities. We will improve volunteer service activities, promote the volunteer spirit of dedication, friendship, mutual assistance, and progress, and create a strong social atmosphere for everyone and everyone. Strengthen the construction of volunteer service teams and extensively develop voluntary service activities that care for others, care for society, and care for nature. Vigorously carry out the learning activities of Lei Feng, create a brand project with distinctive education characteristics, organize and develop activities for the creation and naming of "Lei Feng class" and "Lei Feng youth", and promote the normalization and institutionalization of learning Lei Feng activities. Deepen thematic and practical activities, use the commemorative activities of major commemorative days and traditional ethnic festivals, extensively carry out themed practice activities, enhance the university students' awareness of civilization, and promote moral consciousness.

We must do a good job in major node prevention and handling of emergencies. University stabilizing work should be carried out on major festive days, commemorative days, and important sensitive periods to ensure the normal education and teaching order in universities. In the event of an emergency, immediately initiate an emergency plan to ensure that the event does not spread and does not expand; in conjunction with relevant departments to promote the implementation of education and management of key personnel in universities. The program enhances the pertinence of prevention work; further strengthens resistance to the use of religion in foreign countries to penetrate colleges and campuses and prevent missionary work; conducts in-depth investigations and studies; cooperates with relevant departments to specifically clean up and rectify illegal religious gathering sites around the campus, and perseveres in conducting religious knowledge education and education. And anti-cult warning education work; the establishment of a management database system for stability maintenance, the use of the information consultation system and the research and judgment system, conscientiously doing a good job in the investigation of unstable factors and the resolution of conflicts, so as to grasp the problems early and solve problems in the bud. Combining the solution of ideological issues and solving practical problems, do a good job in day-to-day management work and carry out major special subject researches on maintenance and stability; Intensify the establishment of safe campus activities, continuously purify the campus and surrounding environment, and further improve comprehensive management and safety construction; 
The channel for petitions and visits is to improve the four-in-one network of "network, visit, credit, and electricity" and build a fast, efficient, and low-cost channel for people to express their appeals.

\section{The "Civilized Campus" Brand Culture Construction under the Background of Internet+}

Schools can set aside a section on their official website to launch and update knowledge and videos related to the environment and the environment. They can also broadcast a little knowledge of the ecological environment every day through campus broadcasts and urge everyone to pay attention to environmental protection.

Schools can create an ecological and civil We Chat public platform, update relevant knowledge every day, and collect ecological problems and stories around the students. Actively communicate and solve problems so that students can effectively participate in the construction of an ecological campus; set up related volunteer associations or societies. Supported by the school, increasing the appeal of ecological civilization construction, creating interesting online and offline activities, taking the ecological civilization as the theme of essay writing, creating an environment where everyone is keen on environmental protection, and cultivate students' habit of caring for nature.

Strengthening the construction of network civilization is an important issue in promoting the construction of campus civilization. First of all, colleges and universities should deepen the construction of network culture positions. Strengthen the network content and network culture construction of comprehensive portal websites and ideological and political education websites in colleges and universities. Build an online cultural competition platform, actively organize online cultural theme activities such as the National College Student Photography and Micro Film Competition, guide the teachers and students to participate in the creation of network cultural quality content, and enrich the content of online culture. Second, it is necessary to improve and strengthen the guidance of Internet public opinion. It is necessary to explore the formation of a new mechanism for supervision of online content in universities. It is necessary to strengthen the communication and coordination with the Internet information management, public security, and industry and other departments, and to do a good job of the Internet public opinion in important time periods and sensitive periods. Strengthen the supervision and guidance of online public opinion in colleges and universities, manage the network public opinion monitoring platform and the early warning system and the information work contact and command platform, and promote colleges and universities to actively use social networks to conduct online ideological guidance. Third, we must strengthen the construction of a network management system. Colleges and universities should make clear the leading role of the propaganda department, establish and improve the network construction and management work system, set up full-time positions, implement specialized personnel responsible for the construction of network culture and management, and select relevant personnel from the experts, scholars, counselors, and student backbones to set up a network.

\section{The Impact and Significance of the Research on the Construction of Civilized Campus in Colleges and Universities}

In these daily life, learning and work, they are aware of the responsibility and obligation of energy saving and environmental protection at any time and place, strengthen people's energy conservation and environmental protection behaviors, let energy conservation and environmental protection consciousness subconsciously penetrate the hearts of teachers and students, and make energy saving and environmental protection become only a responsibility of teachers and students. Training is more and more a way of life, work, and learning for teachers and students.

In short, building an ecologically-communicative campus in colleges and universities is not only a requirement of the times, but also a requirement for the development of colleges and universities. We should deepen the education of ecological civilization so that teachers and students in the ecological and civilized campus can see and hear and practice what they have learned. We will comprehensively improve the environmental awareness, ecological awareness, and civilization 
awareness of teachers and students so that the awareness of energy conservation and environmental protection will persist in the minds of teachers and students and become a behavioral habit. And live, work and learn. The good energy conservation and environmental protection awareness and behavioral habits developed by the school are brought to families, units, and societies, as well as ecological civilization. Consciousness is transmitted to the whole society, thus forming an overall atmosphere of ecological civilization construction in the whole society.

\section{References}

[1] Lu Chaojie. "Internet +" background ecology ecology campus brand culture construction of higher vocational colleges [J], Electronic Technology and Software Engineering, 2017 (5) 137-142.

[2] Zhang Lijuan. "Internet +" background of college voluntary service ecosystem reshaping and reform [J], Journal of Inner Mongolia Normal University, 2017, 46 (01): 164-167.

[3] Zhang Shunjun. The construction of a civilized campus and the cultivation of college students' civilized behavior in the connotative development of universities [J], Higher Education Exploration, 2014(12):106-107.

[4] Yan Yangbo. Thinking on the Construction of Civilized Campus in Colleges and Universities [J], Educational Exploration, 2014, 12(282)113-114.

[5] Fan Mingzhu. Research on the Network Public Opinion Environment of University Campus[J], Innovative Education, 2016, (161). 